\title{
Audible identities: passing and sound technologies
}

\author{
PAMELA L. CAUGHIE
}

At the March 2008 conference of the Association for Recorded Sound Collections held at Stanford University, audio historians played what they claim is the first recording of the human voice. It is a presumably female voice singing Au clair de la lune, though the distorted quality of the 10-second recording renders the words no more decipherable than the singer's gender to an untutored ear. ${ }^{1}$ The recording was made in Paris in April 1860 on a 'phonautograph' invented by Édouard-Léon Scott de Martinville (aka Leon Scott), nearly 20 years before Thomas Edison patented the phonograph in 1877. Sound waves captured by a horn attached to a diaphragm vibrated a stiff brush that inscribed the pattern of waves on blackened paper. Scott wanted to produce a visual inscription of human speech but had not yet conceptualised sound as something that could be audibly reproduced; that would be Edison's contribution when he replaced Scott's paper with a more pliable and durable substance: tin foil and later wax cylinders. ${ }^{2}$ The recent recovery of Scott's early inscription foregrounds the historicity of listening itself. As many scholars have pointed out, audition is organised differently by sound technology so that how we hear, not just what we hear, changes. Hearing becomes historical not just physiological; listening becomes technique. A new form of listening entails a new concept of sound itself. 'Phonautograph' means, literally, sound writing itself (which is the subtitle of Scott's 1878 book); thus the term ignores the very machine that is reproducing the voice. 'Phonautograph' suggests that the sound is literally there, textually inscribed on the blackened paper, and thus, technically, is not a re-production.

Embedded in Scott's nomenclature is the germ of the debates that sound technology has aroused in the modernist era over the relative value of - and indeed, the very distinction between - original and copy, live and recorded, authentic and mechanically produced, sincerity and fakery, reproduction and representation. The confusion of those borderlines is graphically presented in

\footnotetext{
1 At the time of writing, the recording was available from $<$ http://www.firstsounds.org/sounds/1860-ScottAu-Clair-de-la-Lune.mp3>

2 Rosen, Jody 2008, 'Researchers play tune recorded before Edison', New York Times, 27 March 2008, <http:// www.nytimes.com/2008/03/27/arts/27soun.html?_r=1\&scp=1\&sq=jody\%20rosen,\%20researchers\% 20 play $\% 20$ tune $\&$ st $=$ cse $>$
} 
the image of the dog with his ear to the horn of the gramophone listening to 'his master's voice' (a trademark first acquired by the London Gramophone Company in 1898 and used by Emile Berliner from 1900), as well as in anecdotes, cartoons, photographs and advertisements from the time in which people mistake the talking machine for a person talking, the mimetic representation for the 'real thing'. That slippage between the live and the recorded, the original and the copy, is precisely the achievement of sound technology; it is not a mistake but what makes it work. In that slippage lies the key to a new, modernist understanding not just of art in the age of mechanical reproduction, but of subjectivity itself. That kind of slippage is one that I have explored elsewhere in terms of 'passing'. ${ }^{3}$

Passing has conventionally been understood, especially in the United States, as a social practice whereby an individual assumes an identity that does not by rights belong to him or her. ${ }^{4}$ Most commonly, it refers to light-skinned African Americans living, or at least socialising, as white, which is how modernists would have understood the term. More contemporary usage expands the concept to include many different kinds of identifications across apparently distinct identity boundaries. The term is often deployed in a pejorative sense, as passing is likely to be associated with impersonation, appropriation or deception. Metaphorical uses of the term (for example, as in 'he's passing as a feminist') might seem to elide the particular historical conditions that motivated passing in its first cultural sense, such as laws against miscegenation, segregated public spaces and community-sanctioned violence. Even in its original historical meaning, however, passing was far more complicated than the notion of adopting a fraudulent identity would suggest. Passing was not just a response to rigidly imposed racial boundaries; it exposed those boundaries - social, legal, corporeal - as cultural, discursive and permeable.

In my recent work, I use 'passing' in its figurative sense to name and conceptualise the experience of subjectivity in late modernity. ${ }^{5}$ Certain social, cultural and technological changes in the early twentieth century produced profound shifts in the understanding and the experience of identity boundaries. That is, both conceptual knowledge and sensory experience eroded the discrete borders of national and personal space on which passing - in its more common understanding as a fraudulent act_-depends. The crossing of borders, literally

3 See Caughie, Pamela L. 1999, Passing and Pedagogy: The dynamics of responsibility, University of Illinois Press, Urbana and Chicago, especially Chapter 1.

4 Although the identity issues that I address in terms of 'passing' are not specifically American or limited to race, 'passing' as a central figure for the complex formation and contestation of identity in modernity is rooted in the racial history and politics of the United States.

5 See Caughie, Pamela L. 2005, 'Passing as modernism', Modernism/Modernity, vol. 12, no. 3 (September), pp. 385-406. I use 'subjectivity' to refer to the concept of what it means to be a subject and 'identity' to denote those cultural categories (for example, race, gender, sexuality, class) through which a subject comes to be seen as an individual. 
and imaginatively, that was at once enabled by and expressed in new technologies, such as radio and film, automobiles and aeroplanes, was not just a means of reducing distances and levelling differences between people; rather, new aural as well as ocular experiences produced by technological reproduction provided evidence - perhaps for the first time, at least on such a large scale- of the production of cultural identity, the way identity is mediated by various cultural forms. ${ }^{6}$ Indeed, the very notion of a coherent identity itself becomes fraudulent in the face of literal and virtual border crossings in the early twentieth century. Sound technologies in particular, insofar as the disembodied voice exists in a 'temporal succession', as Georg Simmel puts it, undermine the very premise of identity, the imperative that a person be self-identical across time. ${ }^{7}$

Passing as a social practice was not a new phenomenon in the modernist era. Not just African Americans but Jews, homosexuals and immigrants had long passed for social, political and economic reasons, as well as for personal safety. ${ }^{8}$ What made passing capture the public imagination in the modernist era as it never had before was not simply a barrage of passing narratives published in the 1920s - including Jessie Fauset's Plum Bun (1929), Nella Larsen's Passing (1929), Walter White's Flight (1926) and James Weldon Johnson's The Autobiography of an Ex-Colored Man (first published in 1912 but which only found an audience in the 1920s). More importantly, the dissemination of cultural products (for example, music, fashion, film) worldwide by new technologies and the forces of mass culture made it increasingly necessary to think of identity in other than nationalist terms. Gender, racial and class identities, structured by and as global commodities, eroded spatial and territorial models of identity. In my use, then, 'passing' signifies the dynamics of identity and identification in the modernist era as a time in which identities - national, personal, cultural - are no longer conceived as bounded territories to be raided or protected but rather as open terrain to be crossed and passed through without fear of trespassing. Or, a more apt metaphor for the topic of this chapter is a wave: a transfer of energy from point to point. Whether by aeroplanes or airwaves, borders of national and personal space were virtually dissolving in late modernity.

6 New media, as Michael North put it, made people 'more aware than ever of the fact of mediation'. North, Michael 1999, Reading 1922: A return to the scene of the modern, Oxford University Press, New York, p. 18. 7 The quoted phrase from Simmel is cited in Halliday, Sam 2001, 'Deceit, desire, and technology: a media history of secrets and lies', Forum for Modern Language Studies, vol. 37, no. 2 (April), pp. 141-54, at p. 145. I will return to Halliday's article later in this chapter.

8 In her contribution to Nancy Cunard's Negro anthology (1933), Heba Jannath writes: 'It must be borne in mind that passing for something which one is not is a very common practice in America. Jews and Mexicans often pass for Spaniards...Jews, Russians, Germans, Italians and Irish frequently change their names into "acceptable" Anglo-Saxon... But because of America's particularly fierce taboo on the Negro, we have come to think that "passing" pertains only to him' (quoted in Scott, Bonnie Kime [ed.] 2007, Gender in Modernism: New geographies, complex intersections, University of Illinois Press, Urbana and Chicago, p. 389). 
In this chapter, I want to argue that the experience of 'voice divorced from sight ${ }^{\prime 9}$ - an experience made possible in the modernist era by the telephone, the phonograph and the radio - serves to destabilise class, racial and gender identities far more radically than the visual imagination usually associated with passing. The mechanically produced voice gives rise to a new kind of subjectivity in the modernist era when subjectivity becomes 'mediated through mass-produced sounds and technologies' such that the subject acquires an ironic distance from itself. ${ }^{10}$ The space opened up by the mediation of subjectivity, creating a slippage between the embodied subject and the disembodied voice, is the site of 'passing' ${ }^{11}$ It is not, however, so much that new sound technologies, especially broadcasting, have disembodied voices; rather, the mechanically produced voice comes to stand in for bodies, or, put differently, subjectivity becomes envoiced. If the scratchy, high-pitched, modulating hum resurrected from Scott's blackened paper can be dubbed 'female' then clearly the demarcation of gender no longer depends on physical evidence or even resemblance.

Walter Benjamin said that 'a different nature opens itself to the camera than opens to the naked eye'. ${ }^{12}$ What kind of 'nature' opens itself to the ear by way of gramophone and radio? What would it mean to conceive identities as audible rather than visual? Just what does identity sound like - a question that returns us again, and anew, to Michel Foucault's resounding question, 'What difference does it make who is speaking?'13

\section{Sounding out modernists}

In his 1931 'sketch', as he calls it, of the withering of manhood in the age of modern technology, Sherwood Anderson singles out the radio as especially alienating in its effects: 'Listen to the voices coming over the radio. There is no reality to the voices. Who can speak naturally over the radio...Something creeps into the voices coming over the radio. They sound false. ${ }^{14}$ Anderson's comment on the lack of substance and sincerity in the radio voice evokes the phenomenon

\footnotetext{
9 Beer, Gillian 1996, “'Wireless”: popular physics, radio and modernism', in Francis Spufford and Jenny Uglow (eds), Cultural Babbage: Technology, time and invention, Faber \& Faber, London, pp. 149-66, at p. 166. 10 Donald, James 2007, 'A complex kind of training: cities, technologies and sound in jazz-age Europe', in Joy Damousi and Desley Deacon (eds), Talking and Listening in the Age of Modernity: Essays on the history of sound, ANU E-Press, Canberra, pp. 19-34, at p. 27.

11 On this definition of 'passing', see Caughie, Passing and Pedagogy, Chapter 1, especially pp. 24-5. As I write there, "Passing" in my use...names a practice in which an original...presence can be neither presumed nor assumed' (p. 25).

12 Benjamin, Walter 1969, 'The work of art in the age of mechanical reproduction', in Hannah Arendt (ed.), Illuminations, Translated by Harry Zohn, Schocken Books, New York, pp. 217-51, at p. 236.

13 Foucault, Michel 1984, 'What is an author?', in Paul Rabinow (ed.), The Foucault Reader, Pantheon Books, New York, pp. 101-20, at p. 120.

14 Anderson, Sherwood 1970 [1931], Perhaps Women, Paul P. Appel, New York, p. 43.
} 
that I term 'passing' and that was analysed and debated by cultural critics of the 1920s and 1930s - from Benjamin to the British Broadcasting Corporation (BBC). If the radio voice sounded false, it was because notions of truth and authenticity were bound up at that time with presence. As Benjamin writes in his 1936 essay, 'The work of art in the age of mechanical reproduction': 'The presence of the original is the prerequisite to the concept of authenticity...The whole sphere of authenticity is outside technical...reproducibility.' ${ }^{15}$ Authenticity itself cannot be reproduced, Benjamin insists, which is why the aura, dependent on presence, 'withers in the age of mechanical reproduction' ${ }^{16}$ Mechanical reproduction itself, however, produces authenticity insofar as the original must be reproduced in order to have any authentic, or unique, existence. 'Authenticity is not reproducible', ${ }^{17}$ but at the same time, authenticity depends on 'a plurality of copies'. ${ }^{18}$ The 'decay of the aura', Benjamin continues, is fuelled by the public's desire 'to bring things "closer" spatially and humanly' by accepting reproductions in place of the uniqueness of things. ${ }^{19}$ The opera singer, for example, now performs in one's living room by means of the gramophone or radio. Although Benjamin uses visual technologies to exemplify the effect of this loss of uniqueness and authenticity - the actor performing before the camera, for example, feels 'exiled...from himself', he writes, quoting Pirandello: 'his body loses its corporeality ${ }^{20}$ — that experience was all the more powerful in sound technologies, where the body was literally elided in the performance.

It was in sound technologies in particular that this anxiety of loss was most deeply felt-by performer and listener alike. In a 1931 BBC broadcast 'Myself and the microphone', Harold Nicholson, addressing the question of sincerity in broadcasting, commented on what Michael North terms 'an entirely new kind of estrangement' ${ }^{21}$ produced by mass media: 'this broadcasting business creates a strange semblance, an unhealthy eidolon of oneself.' ${ }^{22}$ Nicholson's avowal launched a barrage of letters to The Listener, the journal of the BBC, anxiously refuting the kind of insincerity that Nicholson attributed not to the

\footnotetext{
15 Benjamin, 'The work of art in the age of mechanical reproduction', p. 220.

16 Ibid., p. 221.

17 Ibid., p. 243, n. 2.

18 Ibid., p. 221. This is the logic of the supplementary, as Jacques Derrida has defined it. Lisa Gitelman points out that at the same time as new technologies were substituting multiple copies for 'original' handmade ones, American culture came to promote and value products as 'real' or 'genuine'. The 'real thing', then, becomes distinct from the (merely) 'realistic' in modern culture, as in modernist aesthetics (Gitelman, Lisa 1999, Scripts, Grooves, and Writing Machines: Representing technology in the Edison era, Stanford University Press, Calif., pp. 153-4). 'If duplicates are really exact duplicates,' she writes, 'then originality becomes unlocatable and irrelevant, as Walter Benjamin realized' (p. 169).

19 Benjamin, 'The work of art in the age of mechanical reproduction', p. 223

20 Ibid., p. 229.

21 North, Reading 1922.

22 Nicholson, Harold 1931, 'Myself and the microphone', The Listener, vol. V, no. 120 (29 April 1931), pp. 721-2, at p. 722. North makes this comment in discussing Charlie Chaplin's world tour. Fans demanded to see the 'real thing', which was, for them, a 'manufactured image' (North, Reading 1922, pp. 17-18).
} 
individual broadcaster but to the very nature of broadcasting - the 'microphone personality' - which was being produced at the very moment of its mass dissemination. Indeed, The Listener is replete with editorials, reviews, letters and broadcasts on that 'strange semblance'. A recurring debate turned on the question of whether personality was lost when the speaker was unseen, or to what extent the 'purely acoustic clue' was an accurate indication of the personality at the microphone. The worry listeners and producers alike expressed over the possibility of being duped by the radio voice was, however, misplaced; for insofar as gramophone and radio began to break down the distinction between the aural identity and the actual person, the broadcasting voice became literally (to paraphrase Judith Butler) an imitation without an original. ${ }^{23}$

A 1929 editorial in The Listener, 'Voices from the past', ${ }^{24}$ for example, draws the distinction Benjamin later does between representation and reproduction in discussing its new project of recording orators from the past. Rather than rescuing recordings from the past that are not yet audible, as do the audio historians I began by mentioning, the BBC wants to record voices from the past that were never preserved by audio technology - a trickier project to say the least. The $\mathrm{BBC}$, however, that ardent promoter of all things aural, insists that voice suffers on the printed page and, for this reason, re-presenting the voices of the past through broadcasts is a worthwhile endeavour. And while it is not possible to literally capture the voices of the now departed, that does not mean the project is doomed because, the editorial continues, 're-presentation...is better than reproduction; the one is art, the other imitation'.$^{25}$ Here the BBC nearly puts down its own medium in admitting that dramatic re-enactment is superior to mechanical reproduction, even though its motive for producing this series is the preservation of 'voice', and even though the BBC and radio manufacturers at this time insist on broadcasting's fidelity to the real. ${ }^{26}$ And yet that slippage between voice as ethos and voice as real sound - and between representation and representation - is precisely the special niche of broadcasting in the panoply of

23 Butler, Judith 2004, 'Imitation and gender insubordination', in Sara Salih with Judith Butler (eds), The Judith Butler Reader, Blackwell Publishing, Oxford, UK, pp. 119-37, at p. 127. Katie Schaag and I made this argument in a paper we presented at the 2009 Space Between Conference, entitled 'Audible identities: the new aurality and modern subjectivity', in which we reviewed these debates in The Listener from 1929 to 1938.

24 The Listener, vol. 1, no. 17 (May 1929).

25 Ibid., p. 634.

26 Advertisements throughout The Listener for Mullard speakers claim that they give the listener 'truth in radio - every note is lifelike'. Grace Wyndham Goldie, radio drama critic for The Listener, praised reality programs that sounded 'absolutely authentic', immersing the listener in 'the experience of reality itself' (The Listener, vol. 20, no. 511 [27 October 1938], p. 914, and vol. 15, no. 385 [27 May 1936], p. 1022). At the same time, however, the BBC expressed displeasure at Nicholson's suggestion that the broadcasting voice might not be sincere; it also insisted that broadcasting was about 'voice production', not fidelity to the real. And, ironically, the broadcaster was expected to project an authentic personality by mastery of the microphone technique meant to produce the illusion of natural speech. Drawing on Emily Thompson's point that modern sound was 'modern' insofar as it 'exemplified an aesthetic of efficiency in its resultant signal-like clarity' (Thompson, Emily 2002, The Soundscape of Modernity: Architectural acoustics and the culture of listening in America, 1900-1933, MIT Press, Cambridge, Mass., and London, UK, pp. 3-4), James Donald ('A complex kind 
sound technologies. Voice is not so much reproduced (captured) as produced (created) on radio. If the slippage between the original and the recording, the real and the reproduction is the very achievement of sound technology, as I have suggested, identifying the individual behind the voice is no longer a worthwhile task. That identity is in the voice-envoiced - and thus inseparable from the technologies that produce it. This notion of identity is what gives the impression that we are dealing with a new kind of subjectivity.

It was Theodor Adorno, curiously enough, the cultural critic most strongly identified with an anti-technology stance, who intimated this new understanding of subjectivity in his 1928 essay on the gramophone, 'The curves of the needle'. Far from being nostalgic for the 'real thing', Adorno understood acoustic mediation as a thing itself. ${ }^{27}$ 'The technologically mediated [sound],' writes Adorno, 'gains a corporeal proximity which the immediacy of the live performance often denies to those whose goal is a concentrated reception. ${ }^{28}$ Such 'corporeal proximity' (what Benjamin discusses in terms of the desire 'to bring things closer') comes, paradoxically, with the removal of the body of the performer from the audience, the listener. The disembodied but also intimately rendered voice, understood in this way, opens the door to what I have termed 'passing'.

\section{Sounding modern}

Being heard but not seen offers possibilities for re-imagining 'passing' as other than erasure, invisibility, appropriation or blackface. For insofar as becoming a subject takes place through the assumption of identity categories, what happens when those categories - long dependent on presence and sight - are now dependent on voice? One of the works I first turned to in considering aural passing was Julie Dash's 1983 film Illusions. Set in 1940s Hollywood, Illusions takes as its subject matter the common practice of having black women dub the voices of white singers performing jazz or blues songs. In the film, Esther Jeeters (Rosanne Katon), a black woman, is hired to fix the faulty soundtrack when the words sung by the white film star do not synchronise with her mouth movements. Sequestered in the recording studio, Jeeters is never seen

of training', pp. 21-2) argued that audio technology in the early twentieth century was concerned primarily with reducing noise not with faithfulness of the reproduction. In this regard, 'audible identities' must be assessed in terms not of authenticity but of technique.

27 Levin, Thomas 1990, 'For the record: Adorno on music in the age of technological reproducibility', October, vol. 55 (Winter), pp. 23-47, at pp. 39, 44. I discuss Levin's illuminating essay on Adorno further in Caughie, Pamela L. 2010, 'Virginia Woolf and radio, gramophone and broadcasting', in Maggie Humm (ed.), The Edinburgh Companion to Virginia Woolf, Edinburgh University Press, pp. 332-47, at p. 335, from which some of the history of sound technology presented here is drawn.

28 Quoted in Levin, 'For the record', p. 44. 
on screen (though the film audience does see the actor, Katon, who, ironically, is not singing herself but lip-synching Ella Fitzgerald). In her essay on Illusions, Patricia Mellencamp writes that 'the work of the sound track has historically been subservient to the image track', yet Illusions, she continues, 'provides an advanced modeling of representation and reception - critically revising theories of vision through...sound', making 'intellectual arguments through the sound track' ${ }^{29}$ This comment is promising for opening up the possibility of a theory of aural identity. Mellencamp, however, quickly closes off the possibility of reconceiving theories of vision through sound. 'Black performers were in [film] history,' she argues, 'but they were not remembered, there and simultaneously erased', ${ }^{30}$ because they were heard but not seen (as was Jeeters in the diegetic film and Fitzgerald in the film itself). Mellencamp's remark is symptomatic of the privileging she begins by disclaiming: representation, it seems, depends on being seen. Even in discussing a film about dubbing, or vocal passing, critics tend to privilege the visual. To be heard but not seen is to be seen as not there.

But what about voice as a representation? Voice is hardly disembodied. Indeed, voice is a muscle, one that can be trained and thus changed as or more readily than many visible markers of identity. As Douglas Kahn writes in Wireless Imagination, sound transmission fuses 'the spatial features of vibration with the...corporeality of inscription' ${ }^{31}$ - that is, 'transmission was basically the return and reinvigoration of...bodies'. Lisa Gitelman elaborates on Kahn's argument: recorded and transmitted sound 'brought pressure to bear on visual habits, including associations between racial difference and skin color. By removing the performer from view, the technology of recorded sound also removed the most keenly felt representation of the performer's race. ${ }^{32}$ As Dash's film and Mellencamp's essay on it reveal, however, both explicitly and inadvertently, image seems always to triumph over sound when it comes to issues of representation, especially racial. What Dash's film exposes, however, is not only the exploitation of black women by Hollywood producers who would have them do the service work of cleaning up the soundtrack while preserving the whiteness of the projected image. It also exposes the possibility of dissociating racial identity from visual markers that have long defined passing in its first cultural sense. ${ }^{33}$

29 Mellencamp, Patricia 1994, 'Making history: Julie Dash', Frontiers, vol. 15, no. 1 (Winter), pp. 76-101, at p. 83.

30 Ibid., p. 80.

31 Kahn, Douglas and Whitehead, Gregory (eds) 1992, Wireless Imagination: Sound, radio, and the avantgarde, MIT Press, Cambridge, Mass., p. 20.

32 Gitelman, Scripts, Grooves, and Writing Machines, p. 120.

33 In a paper presented at the 2009 Modernist Studies Association Conference called 'Race, records, and American literary modernism', Erich Nunn argues that shifting our focus from the circulation of images and its impact on modernist subjectivity to the circulation of sound 'breaks new conceptual ground by potentially dissociating the meaning of media representations from the visual logic of racial signification in which they are so deeply embedded'. 
If blackness can be disembodied and forgotten in the sound issuing from a lipsynching white star, as critics of Illusions argue, what about another identity: class? In an essay on class passing, Eric Schocket, writing on progressive-era investigators who would go undercover to report on the deplorable living and working conditions of the labouring class, calls such writers 'class transvestites'. These writers, he argues, attempted to bridge the epistemological gap between the classes by 'identifying' with the working classes through 'class impersonation', ${ }^{34}$ appropriating somatic signs of class, such as dress styles. In the course of the essay, however, Schocket shifts from the more common visual and sartorial metaphors to describe passing — such as transvestism, disguise, 'vestigial simulation' - to auditory ones: 'verbal minstrelsy', ${ }^{35}$ 'ventriloquism'36 and the writer as 'mouthpiece' for the lower class. Class, it seems, has a distinct voice that must be represented, as in 'given voice'. ${ }^{37}$ 'Voice' in this formulation, however, has been appropriated, turned into a figure for identity, a virtual representation, thereby forgetting that voice actually has a sound. In his effort to 'give voice' to the working class, Schocket elides the very physicality of voice as evident in a later and related essay in which he focuses on racial markers of class identity - a connection already implicit in his phrase 'verbal minstrelsy'. Writing that in the nineteenth century signifiers of blackness figured the white bodies of the working class as a way of bringing out their condition of dependency and servitude, Schocket concludes that blackness, 'unhinged from any fixed referent', came to signify white labour. ${ }^{38}$ What, however, contributed to this unhinging of blackness from real bodies more than sound technologies, which rendered blackness as skin tone no longer meaningful? What goes begging in Schocket's essay is any analysis of what that shift from vestigial to verbal markers signifies. As in Mellencamp's essay, here, voice is once again subsumed in a theory of representation based on the visual.

For many modernists writing on class, however, voice was literal. In The Road to Wigan Pier, George Orwell writes that when he decided to pass as a tramp, he could disguise his appearance but not his accent. ${ }^{39}$ In Working with the Working Woman, Cornelia Stratton Parker remarks that the speech of working-class women was a key distinguishing feature, so that she had to adopt a different sound, not just a different dress, in order to pass as a factory worker. Their talk, Parker writes of the working women, was 'one of the phases of life which set

\footnotetext{
34 Schocket, Eric 1998, 'Undercover explorations of the "other half", or the writer as transvestite', Representations, vol. 64 (Autumn), pp. 109-33, at p. 110.

35 Ibid., p. 117.

36 Ibid., p. 121.

37 'They must be represented' is the title phrase in Peter Hitchcock's contribution to the January 2000 PMLA issue on 'Rereading Class'.

38 Schocket, Eric 2000, “Discovering some new race": Rebecca Harding Davis's life in the iron mills and the literary emergence of working-class whiteness', PMLA, vol. 115, no. 1 (January), pp. 46-59, at p. 50.

39 Orwell, George 1937 [1958], The Road to Wigan Pier, Harcourt, San Diego, Calif., p. 150.
} 
the stamp of difference on it' ${ }^{40}$ And in her essay 'Middlebrow', Virginia Woolf begins to represent the viewpoint of the lowbrow, but then breaks off: 'To all this the lowbrows reply - but I cannot imitate their style of talking.' ${ }^{41}$

Perhaps the most distinctive voice of the lower class, at least according to T. S. Eliot, was music hall performer Marie Lloyd. In his essay on Lloyd, Eliot remarks that to her credit, 'there are no cinema records of her', for she never 'descended to this form of money-making'. ${ }^{42}$ There were phonograph records, however, though Eliot does not mention that. Although Eliot praises 'the perfect expressiveness of her smallest gestures', he also claims the art of Marie Lloyd lies in capturing 'exactly the tone of voice' of her class - something film was not yet able to do in 1923 when Eliot wrote this essay. If Marie Lloyd is an 'expressive figure for the lower classes', as Eliot says, we could say that Lloyd provides an audible identity for that class. ${ }^{43}$ In his 1934 essay, "The form of the phonograph record', Adorno writes:

There is no doubt that, as music is removed by the phonograph record from the realm of live production and...becomes petrified, it absorbs into itself, in this process of petrification, the very life that would otherwise vanish. The dead art rescues the ephemeral and perishing art as the only one alive. Therein may lie the phonograph record's most profound justification. ${ }^{44}$

It is, one might argue, the recorded sound even more than the stage performance of Marie Lloyd that (pace Eliot) is crucial to preserving her identity and that of the class she represents.

Woolf wrote in 1927 that in the age of the airwaves, 'all divisions are now rubbed out, or about to be', ${ }^{45}$ insofar as the wireless, the talkies and the phonograph

40 Parker, Cornelia Stratton 1922, Working with the Working Woman, Harper \& Brothers, New York and London, p. 12. Parker wonders whether some day, after her class-passing days are over, she will find herself dining 'with the head of the university philosophy department and his academic guests' and will slip and say 'she ain't livin' at that address no more', evoking an uncomfortable silence (pp. 11-12).

41 Woolf, Virginia 1970, 'Middlebrow', The Death of the Moth and Other Essays, Harcourt, Brace, Jovanovich, New York and London, pp. 176-86, at p. 183.

42 Eliot, T. S. 1922, 'Marie Lloyd', in Frank Kermode (ed.), Selected Prose of T. S. Eliot, Farrar, Straus \& Giroux, New York, p. 173.

43 It is the decline of the music hall and the rise of cinema that leads, according to Eliot, to the decline of the lower classes and perhaps to the demise of a culture. 'When every theatre has been replaced by 100 cinemas, when every musical instrument has been replaced by 100 gramophones... when electrical ingenuity has made it possible for every child to hear its bedtime stories from a loudspeaker...it will not be surprising if the population of the entire civilized world rapidly follows the fate of the Melanesians' (ibid., p. 174) - who, Eliot reminds us, are dying of pure boredom. Eliot, like Orwell, worried that mass culture would erase class differences.

44 Quoted in Armstrong, Tim 2007, 'Player piano: poetry and sonic modernity', Modernism/Modernity, vol. 14, no. 1 (January), pp. 1-20, at p. 9.

45 Woolf, Virginia 1980, The Diary of Virginia Woolf. Volume 3, Edited by Anne Olivier Bell, Harcourt, Brace, Jovanovich, New York and London, p. 145. 
crossed national, racial and class boundaries. Todd Avery echoes Woolf when he writes of radio's 'novel ability to perforate social borders, mix social classes, and effect a general democratization of moral valuation' ${ }^{46}$ While a black sound was heard, if not always credited, in talkies of the era, a classed sound was rendered inaudible by the likes of Hollywood diction coaches and BBC pronunciation committees. While there were modest attempts to include working-class voices in BBC broadcasts, their 'accents' were considered to lack authority, so the BBC cultivated a 'classless' English that entailed 'correct pronunciation' and the right accent ${ }^{47}$ — which provided another reading of what Woolf might have meant by 'all divisions are now rubbed out'.

From Leon Scott, who conceived listening as a new form of literacy, ${ }^{48}$ to Thomas Edison, who promoted the phonograph as a means of bringing opera to poor and rural populations, ${ }^{49}$ to the $\mathrm{BBC}$, which saw the formation of a mass public as the very achievement of broadcasting, sound technology was understood as effecting a class revolution. ${ }^{50}$ 'A modern mass public,' proclaims The Listener, 'dates from the inception of broadcasting. ${ }^{51}$ 'The barriers, you see, are down,' declares another editorial, 'the barriers of class and of outward convention and... that vile attitude of mind...that regarded knowledge as the prerogative of the few. ${ }^{52}$ As with Schocket, for the BBC, giving voice to the working classes meant giving them representation on the air. To foster a common and culturally literate public, the BBC produced programs that involved and addressed diverse social groups. Men and women, workers and the unemployed, politicians and artists, scientists and clergymen - all took their turn at the microphone, were published in The Listener and listened in from home. ${ }^{53}$ A 1929 series, for example, My Day's Work, featured broadcasts by miners, dock workers, sewer workers and telephone operators; a 1933 series broadcast the 'Memoirs of the unemployed'; and in a 1937 broadcast a taxi driver gave advice on his favourite books. None

\footnotetext{
46 Avery, Todd 2006, Radio Modernism: Literature, ethics, and the BBC, 1922-1938, Ashgate, Aldershot, UK, p. 37.

47 Cuddy-Keane, Melba 2000, 'Virginia Woolf, sound technologies, and the new aurality', in Pamela L. Caughie (ed.), Virginia Woolf in the Age of Mechanical Reproduction, Garland Publishing, New York, pp. 6996 , at p. 37.

48 Levin, 'For the record', p. 36.

49 Gitelman, Scripts, Grooves, and Writing Machines, p. 137.

50 Johnson remarks that just as print technologies made literacy 'a new marker of class', so sound technologies 'democratis[ed] access to information' and 're-audialised society', thus transforming configurations of class and of power relations in the modern era (Johnson, Bruce 2007, 'Voice, power and modernity', in Damousi and Deacon, Talking and Listening in the Age of Modernity, pp. 117-18).

51 The Listener, vol.16, no. 392 (15 July 1936), p. 118.

52 The Listener, vol. 3, no. 52 (2 January 1930), p. 84

53 Despite such catholicity among broadcasters, most announcers at the time were men of the middle or professional classes. Still, during Hilda Matheson's term as Director of Talks (1927-32), not only did women broadcast regularly but Matheson promoted a style of talk that David Cardiff describes as 'domesticating the public utterance' - an effort to 'soften and naturalize' the voices of national figures and to make broadcasts more informal and conversational and 'intimate rather than intimidating' (Cardiff quoted in Avery, Radio Modernism, p. 45).
} 
of these broadcasts survives in the BBC Sound Archives, but publications in The Listener and manuscripts in the BBC written archives suggest that the BBC staff, which reviewed and rewrote the manuscripts of all broadcasts in the 1930s, literally gave voice to the working class, giving them the supposedly classless style that was known as BBC English. ${ }^{54}$

In other words, however much the BBC saw itself as a democratising force insofar as it aired the voices of the working class, it was far less cognisant of the fact that it produced the very voice, or class identity, it represented. The voice of the working class was an imitation without an original. Nowhere was the creation of an audible identity more apparent than in Geoffry Bridson's brainchild. In 1935, Bridson, in an effort to wrest the BBC style from the 'boil-shirt patronage' of its announcers, created a new voice, an 'ordinary voice', that of Harry Hopeful, an unemployed glassblower played by Frank Nicholls with, Bridson said, 'total sincerity'.$^{55}$ One of the most popular working-class shows, presented as a series of interviews with ordinary people, in fact featured scripted broadcasts and a fictional character. Ordinary people, as Bridson discovered, could not be trusted at the microphone. In one attempt at a live broadcast by miners, their use of 'bloody' and 'bugger' on air caused such an uproar that Bridson sent Olive Shapely into the recording studio with a sign telling them not to use those words. The miners fell silent. The BBC might have sought to incorporate class as a subject matter in its broadcasts, to give it voice in the sense of representing it, but it elided class distinctions in the actual production of voice. Or rather, through the performance of working-class authenticity, the BBC troubled the distinction between representation and re-presentation, opening up a new space for identity formation.

Class accents were an issue in Hollywood films as well as in BBC broadcasts. In Stanley Donen's Singin' in the Rain (1952), set in the late 1920s, when sound films emerged, Kathy Selden (Debbie Reynolds), like Ester Jeeters in Illusions, sang for the silent film star Lina Lamont (Jean Hagen). Initially, when Kathy agrees to dub for Lamont, Don Lockwood (Gene Kelly) objects: 'I couldn't let you do that, Kathy...You wouldn't be seen'-subordinating the soundtrack to the image track. Lamont needs a vocal double not only because her voice is unpleasant but because her grammar and pronunciation are distinctly lower class, clashing with the visual image of her as a glamorous screen star. This is

\footnotetext{
54 For example, while proclaiming he is not qualified to judge great literature, the taxi driver makes comments such as ' $[\mathrm{O}$ 'Duffy] may not have the subtlety of Anatole France. Or the incisiveness of Shaw' (TheListener, vol. 18, no. 455 [29 September 1937], p. 686).

55 Shapely, Olive 1985, Vox Pop, The Story of the First Features Program, 23 December, BBC Sound Archives, The British Library, London.
} 
the reversal of recent Britain's Got Talent celebrity Susan Boyle's performance. Boyle's body, signifying lower-class status, is belied by her voice- a 'class act' that was registered in the shocked reaction of the panel of judges. ${ }^{56}$

Criticism of this film, however, tends to ignore voice as a representation. In her article 'Dancin' in the rain', for example, Carol Clover argues that the film's morality tale of stolen talent restored is driven by anxiousness about the opposite, stolen talent unrestored and uncredited. ${ }^{57}$ Clover says, unlike The Jazz Singer (explicitly referred to in Singin'), which acknowledges, however ambivalently, the blackness of the Hollywood musical, Singin' renders that blackness not just invisible but inaudible ${ }^{58}$ - except, I hasten to point out, for that dropped ' $\mathrm{g}$ '. Focusing on the dancing in the film - which is 'stolen' from African Americans - Clover says that the film's concern with 'miscredit' has 'a racial underside' ${ }^{59}$ Lina Lamont, in Clover's analysis, is the scapegoat for those who not only could not make the shift to talkies but who, like the screen star in Illusions, performed the art of unseen others. ${ }^{60}$

Clover's symptomatic reading, however, elides class differences - the audible difference in the film. There is another irony here. Although in the film Kathy gets credit in the end for her singing talent, no credit is given to Betty Noyes, who sings one of the songs (Would You) Kathy dubs for Lamont, dubbing in turn for Debbie Reynolds. The logic of Clover's argument would seem to make Betty Noyes figuratively black since she received no credit. Noyes, however, was white. Get it? White Noyes/noise - a difference rendered inaudible by the homophone. 'White noise' is, according to John Cage, 'that which we hear but do not apprehend, sounds that exceed or elude our abilities to detect or measure them' ${ }^{61}$ The white noise that is given no credit - heard but not seen — destabilises our ways of making distinctions, bringing us back to that resounding question, 'What difference does it make who is speaking', or singin'? Here I would like to word play further and coin the term 'homophonobia' to name a new anxiety that emerges with sound technology: the fear of not being able to hear the difference.

It was not simply that radio, films and recordings appropriated a black or class sound. Rather, the new aurality of the early twentieth century produced a sound that troubled the very fixed boundaries that notions of appropriation depend on. In an article on torch singer Libby Holman, Jeanne Scheper similarly argues that Holman's aural passing 'destabilize[d] culturally fixated notions of black

56 'Class Acts' is the title of my book-in-progress on passing and class identity.

57 Clover, Carol 1995, 'Dancin' in the rain', Critical Inquiry, vol. 21, no. 3 (Spring), pp. 722-47, at p. 725.

58 Ibid., p. 730.

59 Ibid., p. 737.

60 Ibid., p. 744.

61 Quoted in Morris, Adalaide (ed.) 1997, Sound States: Innovative poetics and accoustical technologies, University of North Carolina Press, Chapel Hill, NC, and London, UK, p. 4. 
and white'.$^{62}$ Holman, a Jew, helped to create a sound that came to be identified with black female blues singers. The fact that Alberta Hunter and Billy Holiday both recorded Holman's signature song, Moanin' Low, suggests how effectively she destabilised audible racial identities. ${ }^{63}$ Holman's singing was, Scheper says, 'a complicated staging of racial and sexual identity through sound', reproducing 'new notions of race and sexuality'. ${ }^{64}$ The dominance of visual metaphors for racial and class identities, however - and indeed, our own worry over the loss of identity boundaries - has prevented contemporary scholars from recognising audible identities as a powerful means of collapsing those boundaries, even as scholarship on the history of sound has proliferated. Once identity is detached from visual clues, passing across identity boundaries becomes all the more likely.

\section{Recent sound scholarship}

What is known as the 'aural turn' in modernist studies - the torrent of scholarship on sound technologies produced in the past decade or so-has not yet provided an adequate and fully theorised account of the impact of sound on the representation and felt experience of identity. For this reason, it might be useful to correlate some efforts in this direction to adumbrate, in the configurations of these scholars' arguments, a theory of audible identities and its implications for the concept, and practice, of passing.

Much recent sound scholarship comments on the effect of this technology on social relations and on the spatial and temporal dimensions of subjectivity. In his essay in Talking and Listening in the Age of Modernity, for example, James Donald remarks that the new technologies have done more than 'disrupt old habits of perception and selfhood...they reconfigured ways of relating to oneself, to others and to the world' ${ }^{65}$ Donald goes on to discuss 'a key feature of this modern experience' - namely, 'a new dynamic of time, space and presence, the transcendence of distance' ${ }^{66}$ As do Paddy Scannell and David Cardiff, Todd Avery and others, Donald focuses on the new community formed through the ear, the audience, and a new cultural persona, the listener, as examples of this 'transcendence of distance', and, I would add, 'difference'. The formation of the listener and the listening community crossed social and national boundaries, producing what Donald refers to as 'a sense of placelessness of everyday

\footnotetext{
62 Scheper, Jeanne 1998, “Take black or white": Libby Holman's sound', Women \& Performance: A journal of feminist theory, vol. 9, no. 2, issue 18, pp. 95-117, at p. 99.

63 Amy Winehouse, who is British and Jewish, replicates that sound today, especially in her hit song Rehab. Scheper's excellent article is the most explicit treatment of aural identities that I have found, although it is limited to Holman's experience.

64 Scheper, "“Take black or white"”, p. 97

65 Donald, 'A complex kind of training', p. 24.

66 Ibid., p. 24.
} 
experience $^{67}$ - a point reiterated by Desley Deacon in her essay in the same volume. ${ }^{68}$ Donald remarks that the voice experienced as "pure signal'69'subjectivity mediated through mass-produced sounds and technologies' presents a reality 'no longer conceivable in terms of individual human qualities' ${ }^{71}$ My research on the BBC suggests, though, that it is not necessarily that individual qualities are lost but that listeners question the extent to which the acoustic signal can be conceived in terms of such personal qualities. Thus, the very meaning of what it meant to be human changed in response to what Emily Thompson calls 'the soundscape of modernity' - an argument other scholars make as well. ${ }^{72}$

Many commentators, however, raise the issue of identity only to sidestep it. 'Of all sounds, none projected and constructed identities more intensely than the voice,' writes Bruce Johnson, noting in particular the revolution in class configurations effected by sound technologies. ${ }^{73}$ Like Thompson, however, Johnson is interested mainly in the dissemination of information, in power relations not in identities. ${ }^{74}$ Most social histories of broadcasting focus, as do Adorno and Horkheimer, on the formation of a new audience and on the 'levelling' process of sound technologies - 'the liquidation of autonomous individuality', as Scannell and Cardiff put it, 'by impressing the stamp of sameness on...everybody'. ${ }^{75}$ Johnson's quotation from a 1897 poem on the recorded voice, however, 'the sound of the voice can never lie'76 — a conclusion at odds with the notion that human qualities have been lost with the disembodied voice and one countered by Sherwood Anderson's experience of listening cited earlier - returns us to the notion of identity. The quoted claim reinforces Lisa Gitelman's point that hearing is historical, as are concepts of authenticity and realness bound up with new aural experiences. Gitelman points out, for instance, that early scratchy recordings were heard as 'just like' the sounds they recorded; in fact, people were said not to be able to tell the difference between the live and the recorded, even though today one cannot imagine how they could fail to detect the noise of the recording devices. (Memorex capitalised

\footnotetext{
67 Ibid., p. 24.

68 Deacon in ibid., p. 80.

69 Donald, 'A complex kind of training', p. 26.

70 Ibid., p. 27.

71 Ibid., p. 27.

72 See, for example: Danius, Sara 2002, The Senses of Modernism: Technology, perception, and aesthetics, Cornell University Press, Ithaca, NY, and London, UK; Gitelman, Scripts, Grooves, and Writing Machines; Hendy, David 2000, Radio in the Global Age, Polity Press, Oxford, UK.

73 Johnson, 'Voice, power and modernity', p. 118.

74 Thompson's definition of a soundscape includes the listener's relationship to the environment - physical and social-including circumstances that dictate 'who gets to hear what' (The Soundscape of Modernity, pp. $2-3)$.

75 Scannell, Paddy and Cardiff, David 1991, A Social History of British Broadcasting. Volume 1: 1922-1939 Serving the Nation, Basil Blackwell, London, pp. 16-17.

76 Quoted in Johnson, 'Voice, power and modernity', p. 118.
} 
on this confusion in its highly successful 1970s ad campaign, 'Is it live or is it Memorex?'.) Similarly, listeners praised the BBC talks in the 1920s and 1930s as sounding intimate and informal, even though they were scripted and readand sound scripted and read to contemporary ears. Notions of what is 'real', in other words, change with new forms of representation. ${ }^{77}$

Gitelman's 1999 book was among the earliest efforts to connect identity formation with sound technologies in particular. Discussing the highly popular 'coon songs' in turn-of-the-century American culture, which 'displaced [the] visuality of racial identity', ${ }^{78}$ Gitelman remarks that in phonograph recordings, as later in radio, one could 'sound black' though 'be' white, as the 1896 Supreme Court ruling Plessy vs Ferguson determined that one could look white but 'be' black. ${ }^{79}$ Concerned with the commodification of race, class, ethnic and national differences, Gitelman argues that demarcating boundaries of identity is as much a matter of patent and copyright laws as it is of the listener's experience of voiceas in the production of 'coon songs', for example, which function to commodify authenticity. ${ }^{80}$ Minstrelsy 'played off a contrived sense of authenticity' ${ }^{81}$ and thus the phonograph record came to market, she writes, loaded with assumptions about 'sameness and difference, about cultural appropriation and assimilation while it also relied upon counterfeiting', ${ }^{82}$ such that changes in laws and in technologies could not be isolated from 'reciprocally changeable parameters of identity' ${ }^{83}$ Whereas Gitelman is concerned with white listeners' consumption of this sound, I am concerned with the subversion of racial authenticity and the permeability of borders that ensue when voice is divorced from sight in the sensory experience of identity. ${ }^{84}$

That slippage between the authentic and the counterfeit is, as I have argued, the special province of sound technology. 'Minstrelsy subverted the questions of racial essentialism on which it fed,' Gitelman remarks. ${ }^{85}$ Yet not just blackness but any audible identity is caught in this contradiction, thus verbal minstrelsy, or racial passing, becomes the paradigm for a reconfiguration of notions of identity, representation, authenticity and realness - hence, subjectivity-in sound technologies. If, as noted earlier, the 'real thing' is now distinct from

\footnotetext{
77 Gitelman, Scripts, Grooves, and Writing Machines, p. 18.

78 Ibid., p. 17.

79 Ibid., p. 17.

80 Ibid., p. 120.

81 Ibid., p. 133.

82 Ibid., p. 124.

83 Ibid., p. 125.

84 Like Eric Lott - on whom she draws in this section of her argument - Gitelman acknowledges that this racial sound was not solely a white construction but was also dependent on recordings of Negro spirituals, on black musical theatre and on the work of black composers and songwriters, for example (ibid., p. 135). It is the miscegenetic history of the production of that sound that I emphasise in my reading of Michelle Shocked's album Arkansas Traveler (see Caughie, Passing and Pedagogy, pp. 15-19).

85 Gitelman, Scripts, Grooves, and Writing Machines, p. 133.
} 
the merely realistic, as Gitelman says, that difference itself is less important than 'the cultural operation of that distinction in the location and experience of representation' ${ }^{86}$

This is precisely what Sarah Wilson explores in her essay on Gertrude Stein and radio. Wilson comments that audiences were resistant to 'actual black voices' on American radio, ${ }^{87}$ as the BBC audience was to women's voices and class accents. Wilson, however, goes on to argue, as Gitelman has shown, that radio "had the capacity to problematize the idea of "actual black voices"' so that the alignment of the vocal with the visual becomes 'dangerously slippery' ${ }^{88}$ Speakers such as Langston Hughes and Richard Wright could identify black without sounding like Amos'n' Andy. ${ }^{89}$ Thus, she writes, 'radio's gift to the mid-century formation of race was aural confusion' ${ }^{90}$ Although dialect was a marker of race as well as class in American culture long before the advent of radio, it was the aural production of identity that created anxiety over - and eventually rendered irrelevant - the fidelity or fakery of that voice in relation to the speaker. Wilson's point is that radio contributed to the instability of 'racial positionings', the 'confusion of voices and identities supposedly signified by these voices' ${ }^{91}$ Poised to pursue this insight in order to revise visual theories of representation through sound, Wilson focuses instead on the parallels between this 'confusion of voices and identities' in radio and in Stein's writings. Still, the 'dangerously slippery' slope that Wilson's essay takes us down leads to a theory of aural passing.

Sound technology raises the possibility of a discrepancy, not a correspondence, between the individual and its vocal embodiment - a discrepancy central to my theory of 'passing'.$^{92}$ The implications of the history of sound technology for class and racial identities in particular would position performers and listeners alike complexly, and uncomfortably, in relation to those we identify as, or with, in aural productions. As Sam Halliday notes in 'Deceit, desire, and technology', if sound technologies are used by 'sincere' people to generate representations of themselves, there exists the possibility that they could generate misrepresentations of themselves - a possibility that worried Harold Nicholson. ${ }^{93}$ Halliday focuses on the connection between vocality and (mis) representation of the self (what I call 'aural passing'), cases in which the voice

\footnotetext{
86 Ibid., pp. 153-4.

87 Wilson, Sarah 2004, 'Gertrude Stein and radio', Modernism/Modernity, vol. 11, no. 2 (April), pp. 261-78, at p. 272.

88 Ibid., p. 274.

89 Ibid., p. 274.

90 Ibid., p. 275.

91 Ibid., p. 275.

92 Passing is 'marked by a discrepancy between what one professes to be... and how one is actually positioned' in society or by others (Caughie, Passing and Pedagogy, p. 25).

93 Halliday, 'Deceit, desire, and technology'.
} 
creates an 'internal nonequivalence' - that is, one's ability to dissemble oneself. ${ }^{94}$ The 'imperative of resembling oneself', Halliday writes, is undermined by communicative technologies and thus we face the possibility that we could resemble no-one, not even oneself: 'Personhood passes over into its opposite, as technologies once used to fabricate identities now dissolve their very principle. ${ }^{95}$

Halliday comes closest to articulating a theory of audible identities that has implications for passing. Yet he too hedges. Like Donald, Halliday suggests that the 'liquidation of the person' is the necessary consequence of 'the imitative potential of technologies ${ }^{\prime 96}$ and thus, citing Georg Simmel, Halliday remarks that it is easier 'to lie to the ear than to the eye'.$^{97}$ If, however, the 'very principle' of self-resemblance no longer pertains, if authenticity is itself a historical and technologically mediated concept, then lying, or passing in its originary usage, might no longer be the appropriate paradigm for audible identities. I draw a different lesson from Halliday's insight. If the principle of self-resemblance no longer pertains then, as J. L. Austin writes of the performative utterance, the copula in 'our word is our bond' breaks down. By introducing the possibility of misfiring into our speech acts, Austin's performative breaks the covenant between word and bond, opening a space between the 'I' who speaks and the ' $\mathrm{I}$ ' who is the subject of that discourse. Passing becomes not just possible but inevitable in the wake of the decoupling of that copula. ${ }^{98}$ The lack of sincerity that Anderson hears in the radio voice, that Nicholson feels in his experience of broadcasting and that Simmel thinks the ear is more vulnerable to is not an attribute of the ' $\mathrm{I}$ ' who speaks but is part of the 'technological substance' of that identity. ${ }^{99}$ Audible identities bring out into strong relief the insight that no identity is integral to itself, that gender, race, class and other cultural markers of identity are always mediated, that they are the performative effects of social practices, cultural institutions and communicative technologies that we come to embody.

The history of sound production, its raison d'être, calls into question the belief that we can get behind the voice to the real personality, the 'real thing' - a belief that has always entailed a disavowal of the performance itself, the audible identity. 'If it is true that through radio we hear what we are,' writes David Hendy, 'it is also true that to some extent we are what we hear. ${ }^{100}$ Here Hendy brings out the reciprocal relation between sound technologies and notions of identity that Gitelman and others also emphasise but too often forget in their

94 Ibid., p. 145.

95 Ibid., p. 151.

96 Ibid., p. 151.

97 Ibid., p. 146.

98 For a fuller discussion of this point, see Caughie, Passing and Pedagogy, pp. 4-5.

99 The phrase is Michael Taussig's, cited in Caughie, 'Passing as modernism', p. 404.

100 Hendy, Radio in the Global Age, p. 214; italics in original. 
own anxious efforts to hold onto the 'real thing' even while acknowledging that the real is historical and, as mediated by sound technologies, inseparable from its performance. It is precisely the inseparability of the identity and the performance that 'passing', in my use, signifies. Responding to Adorno's argument that listening to the radio or gramophone allows for 'greater intimacy' and 'a corporeal proximity', Katie Schaag asks whether the aural experience of the human agent can then be conceived as the 'real thing': aural presence supplanting corporeal presence so that sound itself has its own life (as suggested by Scott's term phonautograph). ${ }^{101}$ What Schaag's prescient question gets at is precisely the singular role of audible identities in the theory and practice of passing.

It is scholarship on passing, I propose, that opens up possibilities for an aural theory of identity (a theory passed over in so much sound scholarship) insofar as the social practice and theoretical articulations of passing introduce a rift between the embodied subject and the performance of identity - the very disjuncture that sound historians theorise in terms of social relations. In turn, cultural histories of sound provide a means for re-conceiving passing in audible rather than visual terms. Exploring the audibility and reproducibility of identity through sound technologies, as I have suggested, could be a more productive way to discuss class as well as racial identity than the visual associations of passing. Indeed, voice could be the most appropriate representation of the performative insofar as voice is more malleable than skin tone or physical form. It also has ethical implications. One can close one's eyes - literally - and that possibility has come to figure closing one's mind, refusing one's attention, turning away from responsibility; but one cannot close one's ears - at least not instantaneously or voluntarily. Perhaps aurality requires or entails a greater responsibility than visual representation because it cannot readily close off response. ${ }^{102}$

\section{Acknowledgments}

I want to thank my research assistants, Erin Holliday-Karre and Kathleen (Katie) Schaag, for their invaluable assistance in researching this essay. I also want to thank Loyola University Chicago for its generous financial support that enabled me to travel to the $\mathrm{BBC}$ archives.

101 Katie Schaag, Email to the author, 15 March 2009.

102 After making this claim in a paper at the 2007 Modernist Studies Association, I found, on further research in The Listener (vol. 15, no. 376 [25 March 1936]) an article by H. Stafford Hatfield that draws this same comparison - 'we cannot shut our ears as we can our eyes' (p. 637) - but without drawing the moral implications from this physiological difference that I do here. 